\title{
Spousal and living related kidney transplantation: our center experience
}

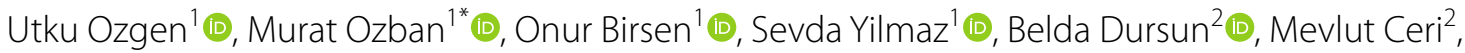 \\ Mesut Eker ${ }^{1}$ (D) and Huseyin Cagatay Aydin ${ }^{3}$ (D)
}

\begin{abstract}
Background: Kidney transplantation is the most preferred type of renal displacement therapy for end stage renal disease (ESRD) patients. More patients developed ESRD. The most important source is the donations from unrelated spouses. In this study, we aimed to compare the transplantation data obtained from the spouses of the patients with the transplantation data obtained from other relatives.

Methods: The data including 167 living kidney transplantations performed between January 2006 and December 2019 were retrospectively collected. The patients were divided into two groups; spousal donor group (n: 53) and living-related donor group (n: 114).

Results: There was no significant difference in delayed graft function in both groups. There were no patients with acute rejection proven by biopsy or considered biochemically in the spousal donor group. With regard to 3-year results in the living-related donor group the patient survival rate was $100 \%$, while it was $98.2 \%$ in terms of graft survival.

Conclusions: In conclusion, similar patient and graft survival rates between spousal donor kidney transplantation and living-related kidney transplantation has made spousal donor kidney transplantation, with possible problems in terms of tissue compatibility, an acceptable alternative to donor supply.
\end{abstract}

Keywords: Spousal, Living-related, Kidney transplantation

\section{Introduction}

The number of patients diagnosed with end-stage renal disease (ESRD) is increasing, in which kidney transplantation is the most common type of renal replacement therapy. As more patients develop end-stage renal disease (ESRD) [1], the issues faced in identifying donor organs lead to problems, increasing the number of cadaveric transplants. In many countries, the donor organs come primarily from living donors, among which living-related donors (LRDs) remain the main source. In our country, donations by relatives of up to the fourth

\footnotetext{
${ }^{*}$ Correspondence: muratozban@yahoo.com

1 Department of Surgery, School of Medicine, Pamukkale University, Denizli, Turkey

Full list of author information is available at the end of the article
}

degree are allowed without the need for ethics committee approval, while the most important sources are unrelated spouses. In the present study, we compare the data related to transplants from spouses with the data from other relatives.

\section{Materials and methods}

Data related to 169 living kidney transplants performed between January 2006 and December 2019 were collected retrospectively, and the cases were divided into spousal donor transplant $(\mathrm{n}=53)$ and living-related donor transplant $(n=116)$ groups. The garnered demographic data included age, sex, HLA mismatch, length of preoperative dialysis and body mass index (BMI), while the medical data included post-transplant graft and patient survival, 
serum creatinine levels, delayed graft function and the presence of biopsy-proven acute rejection. The applied immunosuppressive therapy protocol included the preoperative initiation of corticosteroids and mycophenolate mofetil, and intraoperative basiliximab induction, and the recipients were administered $500 \mathrm{mg}$ of intravenous methylprednisolone before reperfusion. In the cases in which transplants were made from living donors, an additional standard dose of tacrolimus therapy was administered to the recipient in cases of creatinine levels of $<3$. The same standard therapy was continued as a maintenance treatment protocol for the patient. The target for tacrolimus was to maintain an FK 506 trough level of $8-10 \mathrm{ng} / \mathrm{ml}$. Prednisolone was initiated at a dose of $100 \mathrm{mg}$ on the postoperative 1st day, and was reduced by $10 \mathrm{mg}$ every day until a dose of $20 \mathrm{mg} /$ day was reached.

A written informed consent was obtained from the patients and from healthy participants. The study protocol was approved by the Pamukkale University Ethics Committee. The study was conducted in accordance with the principles of the Declaration of Helsinki.

\section{Statistical analysis}

SPSS 22.0 (IBM Corp., Armonk, NY, USA) was used for performing istatistical analysis. Analytical characteristics were given as percentage, mean and SD, or median. The chi-square test was used for univariate analysis of categorical variables. Values of $\mathrm{p}<0.05$ were considered to be statistically significant.

\section{Results}

Table 1 presents the demographic data, as well as data on the immunosuppressive therapy, length of followup, rate of HLA mismatch, rates of function and rejection, body mass indices, graft and patient survival rates of the 53 patients in the spousal donor group and the 116 patients in the living-related donor group. The mean age of the patients was 49.73 years in the spousal donor transplant group and 31.45 years in the livingrelated donor transplant group. All of the transplants were the first transplant surgery undergone by the patients aside from one case. Only one of our patients underwent a third transplantation, having previously received a kidney from both parents (mother and father, respectively), with approximately 12 years of function for both grafts. The patient's spouse was the donor for the third transplant. The patient with the $5 / 6$ mismatch developed no immunological complication during or after the transplantation, and their creatinine value was $0.96 \mathrm{mg} / \mathrm{dl}$ in the postoperative 2 nd year. They remain under follow-up. The HLA mismatching rate was 5.06 for the recipients in the spousal donor
Table 1 Clinical characteristics of transplants from spousal donors and living-related donors

\begin{tabular}{|c|c|c|c|}
\hline & $\begin{array}{l}\text { SD group }(n: 53) \\
\text { median }\end{array}$ & $\begin{array}{l}\text { LR group (n:116) } \\
\text { median }\end{array}$ & $P$ value \\
\hline Recipient age (years) & 49.73 & 31.45 & $<.001$ \\
\hline Donor age (years) & 44.36 & 56.14 & $<.001$ \\
\hline $\begin{array}{l}\text { Follow-up period } \\
\text { (month) }\end{array}$ & 59.18 & 71.12 & ns \\
\hline Recipients'BMI $\left(\mathrm{kg} / \mathrm{m}^{2}\right)$ & 27.12 & 28.96 & $<.001$ \\
\hline HLA mismatches & 5.06 & 3.08 & $<.001$ \\
\hline $\begin{array}{l}\text { Pre-tx dialysis period } \\
\text { (month) }\end{array}$ & 24.17 & 10.91 & $<.001$ \\
\hline Acute rejection & 0 & $1(0.9 \%)$ & ns \\
\hline DGF & $3(5.6 \%)$ & $5(4.3 \%)$ & ns \\
\hline $\begin{array}{l}\text { Patient death (cumula- } \\
\text { tive) }\end{array}$ & $2(3.7 \%)$ & $3(2.5 \%)$ & ns \\
\hline Graft loss (cumulative) & $2(3.7 \%)$ & $11(9.4 \%)$ & $<.001$ \\
\hline $\begin{array}{l}\text { Patient death (first } \\
3 \text { years) }\end{array}$ & 0 & 0 & ns \\
\hline Graft loss (first 3 years) & $1(1.8 \%)$ & $2(1.8 \%)$ & ns \\
\hline
\end{tabular}

$S D$ spousal donor, $L R$ living related

transplant group and 3.086 for those in the livingrelated donor transplant group. There were 19 (35.8\%) full-mismatch patients. No significant difference was identified in the delayed graft functions of the two groups. There were no patients with biopsy-proven or biochemically-suspected acute rejection in the spousal donor transplant group. Biopsy-proven acute rejection was detected in only one patient in the living-related donor transplant group. This patient, who underwent treatment, recorded a creatinine level of $1.8 \mathrm{mg} /$ $\mathrm{dl}$ which has been maintained at healthy levels 2 years after follow-up. The length of follow-up of the patients in the present study ranged from 6 months to 14 years. In our 14-year experience, the cumulative rates of patient and graft survival were $96.3 \%$ and $96.3 \%$ in the spousal donor transplant group, and $97.5 \%$ and $91.6 \%$ in the living-related donor transplant group, respectively. Our 3-year rates, as more cross-sectional data, in turn, revealed patient and graft survival rates of $100 \%$ and $98.1 \%$, respectively in the spousal donor transplant group. In this group, the graft loss resulted from renal artery thrombosis, which was the first case identified in the series. In the living-related donor transplant group, our 3-year results were $100 \%$ for patient survival and $98.2 \%$ for graft survival. An analysis of the serum creatinine levels of the recipients with functional grafts at various times after transplantation is presented in Table 2, in which no significant difference in serum creatinine levels can be identified between the two groups. 
Table 2 Living-related donor group data

\begin{tabular}{|c|c|c|c|}
\hline & Donor & Kinship status & $\begin{array}{l}\text { Relationship } \\
\text { degree }\end{array}$ \\
\hline 1. & FK & Mother & 1 \\
\hline 2. & ET & Mother-in-law & 1 \\
\hline 3. & $\mathrm{GO}$ & Mother & 1 \\
\hline 4. & ME & Mother & 1 \\
\hline 5. & $\mathrm{RÇ}$ & Father & 1 \\
\hline 6. & $A G$ & Mother & 1 \\
\hline 7. & $\mathrm{HE}$ & Brother & 2 \\
\hline 8. & $E B$ & Sister & 2 \\
\hline 9. & FA & Mother-in-law & 1 \\
\hline 10. & $A G$ & Father & 1 \\
\hline 11. & $\mathrm{TT}$ & Cousin & 4 \\
\hline 12. & GK & Sister & 2 \\
\hline 13. & FA & Mother & 1 \\
\hline 14. & EA & Father & 1 \\
\hline 15. & MT & Brother & 2 \\
\hline 16. & IK & Brother & 2 \\
\hline 17. & $\mathrm{AA}$ & Father & 1 \\
\hline 18. & AT & Mother & 1 \\
\hline 19. & NA & Mother & 1 \\
\hline 20. & EK & Mother & 1 \\
\hline 21. & $\mathrm{Al}$ & Father & 1 \\
\hline 22. & AT & Father & 1 \\
\hline 23. & is & Father & 1 \\
\hline 24. & MK & Father & 1 \\
\hline 25. & IF & Uncle & 3 \\
\hline 26. & ÜO & Mother & 1 \\
\hline 27. & MA & Father & 1 \\
\hline 28. & $\mathrm{TT}$ & Brother & 2 \\
\hline 29. & SA & Mother & 1 \\
\hline 30. & SG & Mother & 1 \\
\hline 31. & $\mathrm{FD}$ & Aunt & 3 \\
\hline 32. & $\mathrm{FT}$ & Mother & 1 \\
\hline 33. & MK & Uncle & 3 \\
\hline 34. & $\mathrm{AA}$ & Father & 1 \\
\hline 35. & GC & Mother-in-law & 1 \\
\hline 36. & $\mathrm{HE}$ & Sister-in-law & 2 \\
\hline 37. & $C T$ & Father & 1 \\
\hline 38. & MG & Father & 1 \\
\hline 39. & $N Z$ & Mother & 1 \\
\hline 40. & $A B$ & Mother & 1 \\
\hline 41. & DA & Father & 1 \\
\hline 42. & SK & Mother & 1 \\
\hline 43. & $\mathrm{HZ}$ & Mother & 1 \\
\hline 44. & is & Brother & 2 \\
\hline 45. & $H G$ & Mother & 1 \\
\hline 46. & $A B$ & Sister & 2 \\
\hline 47. & IY & Father & 1 \\
\hline 48. & YS & Uncle & 3 \\
\hline 49. & $\mathrm{AH}$ & Mother & 1 \\
\hline
\end{tabular}

Table 2 (continued)

\begin{tabular}{|c|c|c|c|}
\hline & Donor & Kinship status & $\begin{array}{l}\text { Relationship } \\
\text { degree }\end{array}$ \\
\hline 50. & SA & Father & 1 \\
\hline 51. & EK & Mother & 1 \\
\hline 52. & $\mathrm{HP}$ & Father & 1 \\
\hline 53. & SÇ & Mother & 1 \\
\hline 54. & $\mathrm{HG}$ & Mother & 1 \\
\hline 55. & ÜA & Sister & 2 \\
\hline 56. & ET & Mother & 1 \\
\hline 57. & FY & Mother & 1 \\
\hline 58. & $H G$ & Mother & 1 \\
\hline 59. & PK & Mother & 1 \\
\hline 60. & Öl & Sister & 2 \\
\hline 61. & $\mathrm{HC}$ & Mother & 1 \\
\hline 62. & İG & Father & 1 \\
\hline 63. & $\mathrm{YT}$ & Father & 1 \\
\hline 64. & OÇ & Son & 1 \\
\hline 65. & iş & Father & 1 \\
\hline 66. & $\mathrm{MH}$ & Mother & 1 \\
\hline 67. & SÖ & Mother & 1 \\
\hline 68. & MV & Father & 1 \\
\hline 69. & ÖC & Brother & 2 \\
\hline 70. & EC & Son & 1 \\
\hline 71. & $\mathrm{HÇ}$ & Mother & 1 \\
\hline 72. & MA & Cousin & 4 \\
\hline 73. & HÖ & Sister & 2 \\
\hline 74. & $\mathrm{YH}$ & Mother & 1 \\
\hline 75. & iç & Father & 1 \\
\hline 76. & $\mathrm{Mi}$ & Father & 1 \\
\hline 77. & $A C ̧$ & Father & 1 \\
\hline 78. & BB & Father & 1 \\
\hline 79. & RA & Grandmother & 2 \\
\hline 80. & ÜÖ & Mother & 1 \\
\hline 81. & EK & Sister & 2 \\
\hline 82. & NT & Father & 1 \\
\hline 83. & $A D$ & Brother & 2 \\
\hline 84. & ME & Father & 1 \\
\hline 85. & AŞ & Brother & 2 \\
\hline 86. & MK & Mother & 1 \\
\hline 87. & MK & Son & 1 \\
\hline 88. & ME & Mother & 1 \\
\hline 89. & $\mathrm{DE}$ & Mother & 1 \\
\hline 90. & AY & Brother & 2 \\
\hline 91. & SÜ & Father & 1 \\
\hline 92. & YB & Father & 1 \\
\hline 93. & YY & Father & 1 \\
\hline 94. & EY & Father & 1 \\
\hline 95. & AY & Brother & 2 \\
\hline 96. & $\mathrm{FD}$ & Mother & 1 \\
\hline 97. & FK & Sister & 2 \\
\hline 98. & ÜD & Sister & 2 \\
\hline
\end{tabular}


Table 2 (continued)

\begin{tabular}{llll}
\hline & Donor & Kinship status & $\begin{array}{l}\text { Relationship } \\
\text { degree }\end{array}$ \\
\hline 99. & MÇ & Father & 1 \\
100. & SA & Mother & 1 \\
101. & ZG & Sister & 2 \\
102. & SA & Sister & 2 \\
103. & EÖ & Mother & 1 \\
104. & MY & Brother & 2 \\
105. & OÖ & Brother & 2 \\
106. & ST & Sister & 2 \\
107. & Ş & Mother & 1 \\
108. & HÇ & Father & 1 \\
109. & NE & Mother & 1 \\
110. & SA & Mother & 1 \\
111. & ŞY & Brother & 2 \\
112. & SD & Mother & 1 \\
113. & KA & Sister & 2 \\
114. & ZE & Mother & 1 \\
\hline
\end{tabular}

No minor or major complications were identified during the follow-up of all donors in either group.

\section{Discussion}

The advanced immunosuppressive therapy approaches adopted over the last two decades have led to a rapid increase in the success rates of kidney transplantation [2]. Unfortunately, the number of cadaveric transplantations has not accelerated to any significant degree, and the number of transplant candidates is rapidly rising, leading to an increasing need for organs [3] and prolonged waiting times for transplants [4]. Several transplant centers are experiencing both tissue and blood group compatibility issues, especially those performing frequent crossover transplantations, leading to a greater preference for spousal donor transplants in many centers $[5,6]$. This group, in which both tissue and blood group compatibility issues are common, has become the preferred alternative, particularly due to the high rate of consanguineous marriages in our country. According to the reports of many centers worldwide, graft survival rates are equal to that of transplants from single haplotype-matched living donors, and the graft and patient survival rates are better than with cadaveric transplants [7].

In the present study, children who received kidneys from their parents accounted for the majority of transplant patients in the living-related donor transplant group, explaining the lower mean age of the recipients and the higher mean age of donors in this group. Young age is considered a risk factor for a higher incidence of rejection in young people with a stronger immunological structure than in others [8]. Addressing this issue, Gjertson et al. [9] compared spousal and other genetically unrelated donor transplants, and concluded that graft survival rates were almost the same in both groups. Recent reports in literature suggest that the outcome of transplants is not affected much by HLA group mismatches [10], while several single-center studies have reported graft survival rates to be similar in both living-related and spousal donor groups, but with more HLA mismatches in the spousal donor group [11]. The present study, despite the significantly higher HLA mismatch rate in the spousal donor transplant group than in the living-related donor transplant group, identified no adverse effect of HLA mismatch on outcomes. Both groups had stable postoperative serum creatinine levels, which were usually higher in the spousal donor transplant group at each post-transplant time point than in the living-related donor transplant group, although the difference was statistically insignificant.

The findings of the present study suggest that the 3-year survival rates of both the patient and graft were quite high in both groups. The most important factor contributing to this result is the stringent decisionmaking mechanism applied by our center in regards to transplants with marginal criteria, as well as the stable immunosuppressive therapy protocol with basiliximab induction applied, which is uncommon in many centers. Similar patient and graft outcomes among spousal and related allografts have been reported also in Caucasian [12] and Japanese [13] patients, which it is believed can be attributed to strong immunosuppression, highquality living grafts, spouses of similar age and better drug regimen adherence as a result of the recipient and donor living together [14].

\section{Conclusion}

In conclusion, the similar patient and graft survival rates in the spousal and living-related donor kidney transplant groups suggest that spousal donor kidney transplants, in which tissue compatibility issues may arise, are an acceptable alternative for donor supply.

\section{Authors' contributions}

All authors contributed to the study. Study conception and design: $\mathrm{MO}$, Acquisition of data: $\cup O, O B$, Analysis and interpretation of data: $B D, C A$, Drafting of manuscript: MC, ME, SY, Critical revision: MO, CA. All authors read and approved the fnal manuscript.

Funding

No fnancial support has been obtained in the preparation of this study. 


\section{Declarations}

\section{Ethics approval and consent to participate}

All procedures performed in studies involving human participants were in accordance with the ethical standards of the 1964 Helsinki Declaration and its later amendments or comparable ethical standards. The protocol for this study has been submitted to the Ethical Committee of our institution "Pamukkale University Ethical Committee" on the 22 of Sep 2021-106542.

\section{Consent for publication}

This article has not been presented nor published elsewhere, and no fnancial support has been obtained in its preparation.

\section{Competing interests}

The authors declare no competing interests.

\section{Author details}

'Department of Surgery, School of Medicine, Pamukkale University, Denizli, Turkey. ${ }^{2}$ Department of Nephrology, School of Medicine, Pamukkale University, Denizli, Turkey. ${ }^{3}$ Department of Surgery, School of Medicine, Medipol University, Istanbul, Turkey.

Received: 26 September 2021 Accepted: 14 December 2021

Published online: 29 December 2021

\section{References}

1. Geddes CC, Cardella CJ. Report card on renal transplantation. CMAJ. 2000;162(4):539-40

2. Dyer PA, Martin S, Johnson RW. Critical importance of HLA antigen matching in cadaveric kidney transplantation with high overall survival rates. The Manchester UK Kidney Transplant Team. Transplant Proc. 1992;24(6):2454.

3. Raper RF, Fugaccia E, Shehabi Y. The shortage of kidneys for transplantation in Australia. Med J Aust. 2005;183(1):55; author reply 55.

4. Lebranchu Y, Sirinelli A, Wolf P, Mornex JF. Organ transplantation: epidemiological and immunological aspects; principles of treatment and surveillance; complications and prognosis; ethical and legal aspects. Rev Prat. 2004;54(20):2295-304; quiz 2304.

5. Miura S, Okazaki H, Sato T, Amada N, Ohashi Y, Sato K. Long-term results of spousal renal donor transplants with donor-specific blood transfusions. Transplant Proc. 2001;33(7-8):3417-9. https://doi.org/10.1016/ s0041-1345(01)02473-3.

6. Kute VB, Shah PR, Vanikar AV, Gumber MR, Goplani KR, Patel HV, Munjappa BC, Trivedi HL, Modi PR, Shah VR. Long-term outcomes of renal transplants from spousal and living-related and other living-unrelated donors: a single center experience. J Assoc Physicians India. 2012;60:24-7.

7. Cecka JM. Kidney transplantation from living unrelated donors. Annu Rev Med. 2000;51:393-406. https://doi.org/10.1146/annurev.med.51.1.393.

8. Seikaly M, Ho PL, Emmett L, Tejani A. The 12th annual report of the North American Pediatric Renal Transplant Cooperative Study: renal transplantation from 1987 through 1998. Pediatr Transplant. 2001;5(3):215-31.

9. Gjertson DW, Cecka JM. Living unrelated donor kidney transplantation. Kidney Int. 2000;58(2):491-9.

10. Lazda VA, Mozes MF. An evaluation of HLA cross-reactive group matching on graft survival in deceased donor kidney recipients. Transplant Proc. 2005;37(2):661-3. https://doi.org/10.1016/j.transproceed.2004.12.110.

11. Kizilisik AT, Ray JB, Nylander WA, Langone AJ, Helderman JH, Shaffer D. Kidney transplantation in a veterans administration medical center: 40 years' experience. Exp Clin Transplant. 2004;2(2):238-41.

12. Binet I, Bock AH, Vogelbach P, Gasser T, Kiss A, Brunner F, et al. Outcome in emotionally related living kidney donor transplantation. Nephrol Dial Transplant. 1997;12(9):1940-8.

13. Kikuchi K, Narumi Y, Hama K, Iwamoto H, Uchiyama M, Kozaki K, et al. Kidney transplantation from spousal donors. Transplant Proc. 2000;32(7):1817-8.

14. Watanabe T, Hiraga S. Influence on family psychodynamics on spousal kidney transplantation. Transplant Proc. 2002;34(4): 1145-7.

\section{Publisher's Note}

Springer Nature remains neutral with regard to jurisdictional claims in published maps and institutional affiliations.
Ready to submit your research? Choose BMC and benefit from:

- fast, convenient online submission

- thorough peer review by experienced researchers in your field

- rapid publication on acceptance

- support for research data, including large and complex data types

- gold Open Access which fosters wider collaboration and increased citations

- maximum visibility for your research: over $100 \mathrm{M}$ website views per year

At $\mathrm{BMC}$, research is always in progress.

Learn more biomedcentral.com/submissions 